\title{
Beyond the All Blacks Representations: \\ The Dialectic between the Indigenization \\ of Rugby and Postcolonial Strategies \\ to Control Māori
}

\section{Domenica Gisella Calabrò}

In October 1999, while walking in central London, I was captivated by a larger-than-life image of a fierce, tattooed face emerging from a black background with spiral motifs, which hung menacingly from a building that overlooked the teeming intersection of Oxford Street and Tottenham Court Road. It was an Adidas billboard representing the All Blacks-the New Zealand rugby team-through an imaginative portrayal of a Māori warrior and the patterns of Māori carving art. The image seemed to be calling forth the spirit of Aotearoa/New Zealand and challenging the United Kingdom, which was then hosting the Rugby World Cup, the first rugby union tournament to be held in the professional era.

In the classical rugby nations, ${ }^{1}$ the All Blacks had historically acquired a famed reputation, thanks to their brand of rugby and their openness toward the indigenous elements of Aotearoa/New Zealand, epitomized by the haka-what people tend to identify as a Māori warrior danceperformed before the start of the match. The 1995 introduction of professionalism suddenly placed the team and their status in a globalized, lucrative, and hypercompetitive context (see Scherer and Jackson 2007; Ryan 2008; Harris 2010). To preserve and reinforce its profile in a similar context, New Zealand rugby set out to place emphasis on the Māori warrior tradition, iconography, and ritual and on the egalitarian ethos on which New Zealand has forged its national identity. Through mass advertising and branding, the All Blacks have thus gained worldwide visibility and have come to be associated with the noble warrior spirit "inherited" by the indigenous inhabitants and with the supposed cohesion of indigenous

The Contemporary Pacific, Volume 26, Number 2, 389-408

(C) 2014 by University of Hawai'i Press 
and nonindigenous people and cultures encapsulated in the motto "one country, one team."

Following that episode in London, I embarked on a personal voyage of discovery that led me to become familiar with Aotearoa/New Zealand. ${ }^{2}$ I looked at everyday realities facing Māori against the images depicted in the rugby context, ${ }^{3}$ until I started to actually investigate the nature and the implications of the Mãori relationship with rugby. The research (Calabrò 2OII), based on one year of fieldwork in New Zealand (February 2008-March 2009), has confirmed that relationship to be a dynamic nexus of opposing and interplaying forces, which reflect the powerful and intricate combinations of meanings played out in sport, as illustrated by Niko Besnier and Susan Brownell (2OI 2) and analyzed in this special issue. Such associations echo the murky nature of relationships between Māori and Pākehā (non-Māori of European origins). This has been emphasized by the Treaty of Waitangi, New Zealand's egalitarian ideals, the government's adoption of a policy of biculturalism since the late I970s, and continued Māori struggles for recognition and self-determination, which have hitherto informed their lived experiences (see Coates and McHugh I998; Durie 1998; Walker 2004). At the same time, the Māori relationship with rugby mirrors the multifarious ways Māori define their identity/ ies, relate to ngā taonga toku iho (Māori heritage, ie, the "treasures" inherited from their ancestors), and experience indigeneity in contemporary society. ${ }^{4}$

The All Blacks embody real aspirations and experiences of oneness that transcend differences and divisions. ${ }^{5}$ At the same time, they encompass Māori desires for self-determination, aspirations both for cultural continuity and distinctiveness and, in the professional era, for economic and social self-realization. Māori rugby being vested with indigenous sociocultural meanings is a nuance not always easy to pick up from more generalized rugby discourse, and it becomes evident when focus is shifted away from the All Blacks onto indigenous contexts such as the Māori All Blacks team, the annual Māori rugby tournaments sanctioned by the New Zealand Rugby Union (NZRU), Māori school rugby, the Māori clubs, and the tribal-based sporting competitions. Through rugby, Māori "tell stories" revolving around concepts such as mana (spiritual prestige and power) and whanaungatanga (being like a whānau [Māori family]) (see Palmer 2005 ) and featuring an ideal of personhood that balances physical prowess, mental strength, and cultural awareness, as suggested by the Māori national team Tìmatanga haka. ${ }^{6}$ Māori rugby is, therefore, an example of 
sport being used to challenge colonial domination (see Appadurai I996; Bale and Cronin 2002) and the forms of sociopolitical marginalization and inequity that are masked by the egalitarian policies.

Yet, while struggling to explicitly identify rugby as a marker of contemporary Māori identity, many Māori will also claim that "rugby is just a game" (compare Kwauk, this issue). Others dissonantly locate the meaningfulness of rugby to Māori in the past and disapprove of the current association of rugby with Māori culture or political and economical aspirations. Some advocate a new kind of narrative in which Māori rugby becomes emancipated from colonially derived institutions and sport definitions. Such diverse and often discrepant views are emerging along with increasing indigenous awareness of the subtle machineries of control and exclusion that New Zealand rugby as an institution has been deploying against the minority it has incorporated. These strategies can be discerned in the ways that power structures have tended to silence the history and the creativity of Māori rugby when they are perceived as colliding with the wider national interests (Ryan I996, 2005; Hokowhitu 2009). The problematic nature of such relations and the divergent Māori responses powerfully (re)emerged during the celebrations of the centenary of the Māori team, as I witnessed during a brief sojourn in New Zealand in 2010.7 With these issues in mind, many Māori had seen deeper implications in the NZRU announcement that in 2009 the Māori team would not be assembled due to financial difficulties. Bill Bush (Ngāti Tūwharetoa, Te Whānau-ā-Apanui; ${ }^{8}$ former top-level player for the All Blacks and the Māori All Blacks in the I970s and I980s; former coach of the Māori Colts and now activist for Māori rugby) said that it felt "like they got rid of the language ... they're trying to get rid of the rugby now."

Another issue is that the perceptions of the hyperphysicality and rebellious "nature" of Māori bodies reflect a history of politics that has aimed at circumscribing their aspirations and their possibilities within physical arenas (Hokowhitu 2003, 2004a) and thus has contributed to social inequality (see Bourdieu I978, 1990). Nevertheless, due to their alleged ill discipline, these same "bodies" seem unfit for the globalized professional world, and Māori rugby is reduced to a commercial representation. On the other hand, it should be noted here that all male players are eligible for selection for the various national teams (All Blacks, Junior All Blacks, Under 20s, Schools, Heartland xv, Sevens), but only Māori who have their whakapapa (genealogy) verified by the team's kaumātua (cultural advisor) may be eligible for the Māori All Blacks. To many non-Māori, this falls 
within the privileges they believe Māori receive in New Zealand and is ultimately seen as discriminatory by other ethnic groups.

This article, therefore, sketches a global overview of the dialectical Māori relation to rugby, considering how Māori have made rugby their own and the limits of such indigenization against the constraints of politics and the demands of professionalism. Māori rugby is as varied as the tribal groupings and localities in which the game takes place, and my research did not focus on a specific geographic or tribal area. During the Māori regional and interregional tournaments, I followed the Te Tini a Maui/Central Māori rugby region, corresponding to the lower part of the North Island. With regard to Māori school rugby, I observed most closely that of Te Aute College, a Māori boarding school situated in the same rugby region. Informal conversations and interviews involved people who self-identified as Māori and had been directly or indirectly involved with rugby. I formally interviewed people with whom I was familiar or people to whom I was introduced by other Māori who acted as intermediaries; my interviewees included four women and eighteen men, some of whom are key figures in Māori rugby. ${ }^{9}$ The people I met at the School of Māori Studies at Victoria University of Wellington, which hosted me during my stay in New Zealand, acted as my initial intermediaries and meaningful relations. Based on firsthand interview materials, I argue that All Blacks representations conceal more than they reveal of the connection between Māori and rugby they allude to, because the space within and surrounding rugby is ambiguous and multilayered, thus allowing Māori to be viewed in new ways, both as sociocultural agents and as indigenous subjects trying to cope with enduring manifestations of colonialism.

\section{Indigenizing Rugby in New Zealand: Cultural Revitalization and Political Strategies}

The concept of "Māori rugby,"10 regularly evoked by my informants, includes a range of aims and approaches unique to Māori and their history that allow us to recognize the relation of Māori to rugby as a "phenomenon of indigenization" (see Appadurai 1996; Sahlins 1999). The early endeavors of Māori players who strongly contributed to the definition of New Zealand rugby sounded like a "cry for tino-rangatiratanga (sovereignty)" and thus emerged as an expression of "creative subversion" (Hokowhitu 2005, 90; 2009, 2320). In the second quarter of the twentieth century, Māori integrated the game into their community dynamics, 
thereby demonstrating sociocultural resilience as well as a persistent creative and strategic approach to rugby. ${ }^{11}$

In Māori contexts, rugby is incorporated in social encounters supported by indigenous ceremonial customs such as the powwhiri (the ritual of welcome) and the display of manaakitanga (hospitality). ${ }^{12}$ The match could actually be viewed as a metaphorical enactment of a pōwhiri: an allegorical battle-opened by the teams performing the haka on the most important occasions-between two groups, each representative of a community, who will finally reconcile through the hongi (greeting consisting of the pressing of noses) and socialize in the "third half." In this sense, Māori rugby becomes a ritual (see Lévi-Strauss 1962; Guttmann 1990; Archetti 1999). In the rugby context, Māori have been able to get together to discuss ideas and projects, transmit their knowledge to the younger generations, reinforce their sense of identity, and exercise their culture in a communal setting (Buck in Sorrenson I986, I:I35; Te Rito 2007).

As a platform of competition and cooperation at both the local and national level, rugby has helped to maintain the notion of mana, based on the interdependence between the individual and the community (see Metge 1976, I986), and it has therefore become a site to identify leadership (Te Rito 2007; Winiata 1967). In our conversations and interviews, several Māori stated that playing is about "putting your mana on the line." The players' deeds on the field confirm and highlight the prestige of the tribal communities they belong to, which in turn acknowledge the enhanced prestige of the players. My interlocutors reiterated that Māori players facing opportunities to display such mana should always "give it a go." Accordingly, while they believed that winning was the ultimate goal, they relativized its importance by placing emphasis on the aesthetic, cultural, and moral dimensions of the game. As suggested by many of my informants, the haka's performance should also partly be viewed as a dramatization of the team's mana as well as an acknowledgment of the mana of their opponent.

All the Māori I talked to also identified a particular way of coming together on and off the field. "We call it whakawhanaungatanga," stated both Whetu Tipiwai (Ngāti Hineuru; a prominent kaumātua [elder] in the Hawkes Bay region, representative of the Central Māori region at the Māori Rugby Board and kaumātua of the Māori New Zealand team since 1994), and Brendan Watt (Ngāti Ranginui, Waikato, Ngaitirangi; a semi-professional player who captained the Te Tini a Maui senior team in the 2009 Māori interregional tournament in Christchurch). To recreate 
(whaka) the culture (nga tanga) of what has been identified as the basic Māori social unity (whānau), they develop connections through sharing experiences and working together according to tikanga (values and customs) such as kotahitanga (unity), cooperation, collective decision making, mediation, humility, honesty, awhi (support), and aroha (compassion) (Metge 1995). The strong sense of rugby's camaraderie has proved congenial to the creation of such relations, raising up the rugby team as an example of metaphorical whānau. ${ }^{13}$ To Tipiwai, whakawhanaungatanga means that "the boys look after one another, and the boys can correct, they can direct one another. .. . That's an important thing for the sport, that's the kotahitanga, the unification of cultures, of tribes, of people. And when that's encompassed in yourself and fourteen other guys are like you, you know you're the same thing." As a consequence, putting their mana on the line also consists in "being there for each other." Watt identified whakawhanaungatanga as the element that enabled ad hoc Māori teams like the ones competing in the Māori rugby tournaments to easily and quickly coalesce and achieve success on the field. Within these metaphorical whānau, players, coaches, kaumātua, and other staff tend to relate one to another in accordance with the tuakana/teina (elder/younger; mentor/ novice) model, based on the principles of complementarity and reciprocity (see Te Rito 2007).

In a time when many Māori are estranged from conventional aspects of Māori culture, the cultural dimension of the Māori tournaments or the Māori national team and their utility in terms of cultural revitalization is sometimes questioned. Some suggest that the annual tournaments or the occasional games of the Māori team cannot fill all of those deep absences or that the association between rugby and Māori culture may actually be instilling colonially derived ideas of Maoriness. In fact, I argue that such events provide opportunities for powerful enactments of whakawhanaungatanga and thus contribute to maintaining elements of indigenous society that are invisible and usually taken for granted but are the primary elements that distinguish Māori from non-Māori, inasmuch as they determine the way people relate to one another.

The Māori I talked to often declared feeling particularly comfortable playing on Māori teams. Dallas Seymour (Ngāti Hikairoa; former toplevel player with the Māori All Blacks, Sevens, and All Blacks in the transition to professionalism; and current relationship manager at Sport NZ, the government agency for sport and culture (formerly SPARC) powerfully 
explained that those Māori team spaces represent a turangawaewae (a place where Māori can stand), no matter how the players conceive their Māoritanga and how knowledgeable they are in traditional terms, and this encourages them to (re)discover their cultural roots:

Within the teams that have Māori context, in some ways you don't have to ... make excuses or I guess to tone it down to make other people feel at ease.... Like within the Māori New Zealand team, for instance, there are guys who are totally comfortable and fluent, but the majority of the guys, I guess we're pretty much on the same boat, we really don't know much about our culture, but when they come into it, they're totally at home straight away and that makes us grow as people. . . You couldn't help learning in that environment.... You're gonna be judged on the field, but in terms of Māori, we won't judge you, you're Māori, and now you're a whole person, I guess. . . . It's like going to kainga [home], like everyone goes to their own area, to their own marae [ceremonial center], and that's where you are the most comfortable, 'cause you're within your own family and you're gonna be nurtured and looked after and put under pressure, but in a nice way.

There is something stringently political in the Māori use of rugby as a site to guarantee sociocultural continuity and assert their tribal identities in a colonized landscape. Still, I contend that rugby has become the king of sports in Maoridom thanks to its status as a national icon, for such status entails political opportunities for national recognition and restoration of their mana as tangata whenua (people of the land) in Aotearoa/New Zealand (see King I983, 298; Hokowhitu, 2004a, 209). This context has allowed for further aspirations of unity with Pākehā alongside contemporary challenges to their power and certain negative representations of Māori. Consequently, rugby has played a prominent role in the construction of a pan-tribal identity whose defining trait is its indigenous status in opposition to the colonial or postcolonial forces. The strong political value that rugby has acquired over the past century has contributed to its paradoxical position as a strong expression of contemporary Māori identity, whose official status seems to be unaltered by the gradual erosion of localized Māori rugby. ${ }^{14}$ Still, the political dimension of the indigenization of rugby can be quite subtle. It can be seen in the ways that Māori culture has influenced the New Zealand national game and has shaped its uniqueness, even if the country usually fails to recognize it; this indigenization justifies Māori pride in being part of the All Blacks legacy. 
From the Material Māori Body to Its

Representational Virtual Presence

Rather than talking about Māori rugby, non-Māori speak of "Māori flair," referring to indigenous performance on the field (see Grainger 2009; Clément, this issue). This concept is polyvalent, a point Brendan Hokowhitu has repeatedly framed $(2004 \mathrm{a}, 2004 \mathrm{~b}, 2008,2009)$. It not only evokes the qualities of Māori on the field but also implies recognition of Māori success. Not surprisingly, it is frequently used by Māori too. Nonetheless, in suggesting a natural aptitude for rugby, such a discourse silently excludes Māori from intellectual or technical realms of the society, which are valued and important, and instead emphasizes Māori contributions to the physical aspect of the game only. The discourse that naturalizes Māori physicality has another corollary: indiscipline. ${ }^{15}$ A Māori player starting a fight on the field typifies dominant representations, suggesting that powerful play results mainly as the sublimation of an inborn violence.

Most of my interlocutors reported and critiqued the stereotypes such representations engendered. Debunking the representation of Māori rugby as mere entertainment, Seymour stressed that "you want to do well" because "your ancestors [will be] watching over you" and that Māori players represent the larger Māori community and its history, so "there's a real sense for me of ... you're playing for something much bigger, much bigger than you ... not just playing the game. . . .In Māori contexts ... you're playing for yourself, your family, your, your culture, and . . for Māori in general, and that's a responsibility but also appealing, in a way."

These considerations echo the vision of rugby as a space where the player has "to put one's mana on the line." Seymour also blamed the "fantasy, for want of a better word, around Māori rugby being just about throwing the ball around," which engenders the idea that "Māori rugby doesn't fit with having a technical appreciation for the game." However, Caleb Ware (Ngāi Toa; a young man who was then relocating to Australia to play semi-professional rugby) noted that "maybe the stereotypes are pretty spot on," defining Pākehā players as "more methodical" and Māori as "crash and bash." Māori have actually became famous for an "irreverent" playing style, which privileges the ball game-running, throwing the ball around, tackling, sidestepping-over kicking for territory and trying to work their way out. This approach to the game apparently substantiates the idea of rugby merely conceived as a physical experience and fun, 
in a similar vein to Samoan contexts (see Clément, this issue). Still, most of my interlocutors emphasized their appreciation of the technical dimension of the game, and while they-women included-did acknowledge that playing rugby could serve as an outlet for aggression, they related that to an ideal of psychological health where frustration must be expressed rather than repressed (see Metge and Kinloch I984, 28).

The "unorthodoxy" of the Māori game should also be framed in terms of a culture that appreciates experimentation and autonomy in the learning process (see Metge and Kinloch I984, 39). To Hokowhitu, Māori style of play could as well be regarded as a sign of resistance, "in that it challenged New Zealand investments in winning, fulfilling and triumphing over Others" $(2009,2325)$. On the other hand, the stress on physical prowess is certainly influenced by a discourse that has authenticated Māori physical skills and courage on the war field or in the sporting arena as their defining traits and most valuable characteristics (Hokowhitu 2004a, 2004b, 2008). Furthermore, if the majority of the Māori I interviewed had an all-encompassing appreciation of rugby, they did refer to other Māori narratives-usually from vulnerable or dysfunctional socioeconomic contexts-that sanctioned the discourses they criticized.

In this regard, Matt Te Pou (Tūhoe; New Zealand Māori coach from I 995 to 2005 , during which time the team achieved unparalleled success) strongly critiqued the Māori overuse of the term "flair" in that it contributed to turning the "fantasy" into reality. He thus recalled his experience when he first started coaching a group whom he jokingly described as

a team down the road that used to drink more than they played rugby. ... Now, Māori like to run the ball, to throw the ball around. ... Because they're running the game, they risk, yeah, Māori players have got their flair. When I first got into a Māori team, they said, "We don't have a game plan, we've got flair." As you know, the old people, they were in the Islands and they decided to come this way, and the reason why they left those places, it was because there was the warfare. The reason why they left was the survival. Now, do you think the chief said, "Now everybody jump in the canoe, we're going on this three-month trip on the open Ocean and I've got no plan! I've got flair"? [laughs] No, no, I think they must have had a massive plan, eh? So we're gonna have game plans, you know. That was my story. I used to walk around and say, "Bloody flair!" [laughs] They have got flair . . . but if you play a game, you've got to be disciplined, and the old Māori sort don't like that. Flair can be channeled. 
Te Pou managed to lead this team to the Air New Zealand Cup. Based on his experience, he argued that leadership and the respect given the players are key in making the Mãori players successful and responsible, because

people are led, I never managed people, you manage things, you know? . . . And if they're good enough, they then jump into the front and you lead them from the back. ... So in rugby, what I used to instill in the players is that they're on the paddock, they're on the field, and the leadership I want from them is shared discipline. . . . It's about decision making, so later on, once they've started to know where we go, I can get them to virtually write the game plan-not only the coach is right-by getting to own it.... So you know that's just a matter of empowering them and getting them to the right level ... and while we were winning I had to make sure that everyone had the opportunity of stepping up, so I used to sit down on one to one and ask them what they wanna do, where they wanna go.

This approach contains the notions of cooperation, unity, and reciprocity and the view of the leader as a guide, all of which shape the Māori family. It all goes back, then, to the idea of the Màori team as a metaphorical whānau. Thus, "indiscipline" could partly be ascribed to a coaching approach that ignores or glosses over cultural differences between Māori and Pākehā and does not make the players feel respected (see Hippolite and Bruce 20I0). According to my respondents, the fast-paced and demanding environment of professional rugby also does not encourage an approach that accounts for cultural difference.

However, the dominant essentialization of Māori rugby and the frequent internalization of such stereotypes seem to impede the possibilities Māori have to make it to top levels, where winning and discipline are imperative. The Māori situation then becomes exemplary of a sport discourse problematizing and eventually discriminating against the minority it includes and, to some extent, relies heavily on (see Besnier and Brownell 20I2, 450 ). This reality clashes with the great expectations of Māori young generations. Like the youth of other Pacific countries observed in this issue, many of the boys attending Māori boarding schools and participating in Māori rugby tournaments are caught in "the politics of hope" generated by professional sport (see Besnier and Brownell, 20I 2, 452; Dewey 2008; Grainger 2009). In this scenario, the encouragement of some whānau to the aspirations of the rangatahi (youth) has been wavering, whereas several people involved in Māori rugby support them, hoping that the economic prospects and the educational possibilities rugby now brings might 
keep them off the street. But then, as the kaumātua Tipiwai noted, "It's sad ... it's really sad when our boys try so hard to make these teams and they don't make it ... so we lose them." By losing them, he was also referring to the migration of Māori players overseas. There are long and complex histories of Māori travel, for a variety of purposes (sport included), which have certainly provided opportunities for the enhancement of their mana (see Sin and Stillman 2005; Teaiwa and Mallon 2005). The people I encountered actually expressed strong pride when talking about Māori rugby men being involved in foreign championships and selected for other national teams. Still, various Māori voiced ambivalent feelings toward the transnational movement of their rugby players. The sociocultural and political role attributed to rugby seems to engender the feeling that Māori should play rugby in their whenua (land) and with their people.

More generally, if the dominant discourse has historically reduced the Māori man to the Māori body, professionalism seems to have entailed the replacement of the indigenous bodies by their own simulacra. The Māori contribution to the current game is often exposed in the powerful branding of Māori culture, such as the billboard mentioned in the first paragraph of this article, ${ }^{16}$ which sometimes generates the impression of its being used as a mere marketing tool in a (mis)appropriation of indigenous culture by global forms of capitalism (see Jackson and Hokowhitu 2005). Such a feeling is reinforced by the New Zealand Rugby Union's frequent lack of understanding of Māori protocols regarding the management of their culture, which Māori view as collective property and a taonga (treasure; see Metge 1995, 310); the NZRU representatives tend to consult superficially or at the final stage or might skip Māori rituals such as the blessing of designs. Similarly, the haka has long been an object of controversy (see Jackson and Hokowhitu 2005). A few of my informants noticed that even Māori indiscipline—a domesticated version of it—is being marketed. In Te Pou's words, "The public wants spectacular actions," so "flair makes good business sense."

To some Māori, the Māori presence in New Zealand rugby representations overshadows a reality in which the niche of Mãori players is being taken over by Pacific Islander players. They bring out similar characterizations, I was told (although some of these may be revealed and embodied in different ways) and thus a similar game, which allows the All Blacks to maintain a localized masculine identity (see Besnier and Brownell 20I2, 453; Grainger 2009), but the Pacific Islanders are perceived by mainstream society as being less "problematic" and more "authentic" Polynesians 
than their Māori counterparts. The conflation as well as the separation of Māori and (other) Pacific People that has emerged in rugby union can be viewed in terms of ambivalent kinships, in which the two are connected by cultural proximity (the Māori acting as the tuakana due to their status as tangata whenua) and alliance in civil rights activism and separated by their different status within New Zealand (indigenous versus migrant) and the sociopolitical implications such status entails (Teaiwa and Mallon 2005).

However critical, most of the Māori I encountered hardly ever spoke of racism and seemed quite cautious regarding the labels they applied to themselves. ${ }^{17}$ More commonly, they talked of Pākehā fear or lack of cultural understanding. While the desire not to fuel the stereotypes of Māori playing the race card and asking for privileges certainly could account for that reluctance, I believe that the hope that their rugby aspirations would not be interpreted as separatism had equal weight in their self-censorship. A degree of inclusiveness in New Zealand rugby and the society at large cannot be denied, nor do Māori want to deny it. As Christina Rangiata Hawkins (Ngāti Kahungunu, Tainui, Waitarangi, Hauraki, Maniapoto; an amateur player who had also participated in the Māori rugby tournaments) stated, "We are meant to be one, and in a sense we are one, 'cause I'm not just Māori." Such positioning mirrors the ambivalence inherent in the Māori relationship to rugby and of the larger contemporary Māori aspirations, even though dominant discourses tend to deny the possibility of multiple forms of representation.

\section{CONClusions}

The deep connection between Māori and rugby that is (mis)represented in the symbolism of the All Blacks is multilayered and opaque insofar as it is not always possible to neatly demarcate when indigenous agency is suffocated or expressed and when equality is recognized or denied. This situation has resulted in the diversification of Māori experiences and perceptions of rugby while simultaneously challenging the narrowness of dominant perceptions of indigeneity. Building on the work of Hokowhitu in his deconstruction of dominant discourses surrounding Māori sporting identities, this article has further probed the discords and multiplicities of meaning so intricately aligned with rugby, privileging an ethnographic approach that focuses on the intimate realities of Māori rugby. Future debates need to explore how the nuances that have herein emerged con- 
tinue to hinder or to empower Māori to express their indigeneity. Further, what kind of "space" is possible for Māori in New Zealand rugby and, by extension, in contemporary New Zealand society as a symbol that would honor the egalitarian model the nation officially abides by?

From Māori perspectives, both their celebrations and rejections of Māori rugby can be ascribed to indigenous awareness of living in a society that has only partially moved on from its colonial past. In this context, to unconditionally embrace rugby and the Māori warrior spirit means to partake in the process of the exclusion and control of Māori people. On the other hand, ignoring rugby and denying its importance risks further marginalizing the numerous youth who struggle both to locate themselves in New Zealand society and Māori contexts as indigenous actors and to surmount negative expectations at school and within mainstream society. In a worldview that upholds complementarity, rugby and educational achievements could eventually emerge as complementary elements. The lives of several Māori rugby leaders point in that direction, including educational accomplishments and involvement in areas like business, politics, academia, and community leadership. Having said that, rugby also seems to still have the potential to promote cultural continuity and revitalization in the way it enacts whakawhanaungatanga.

In any case, most people I talked to advocated additional maneuvering within New Zealand rugby in order to fully express their rugby style, their identities, and their political, cultural, and economic goals (compare Hokowhitu 2009, 2330). To one informant, it meant the possibility for overseas Māori to play on the national team, suggesting that the control of "white institutions" over Māori rugby stretches so far as to constrain the definitions of the Māori nation represented by the Māori All Blacks. Still, the mere discussion of similar ideas seems unfeasible in a country that accuses the Māori team of being racist. In this regard, we have to be cognizant that many non-Māori still view Māori as a race rather than a culture, notwithstanding the government's adoption of biculturalism and the replacement of the blood quantum criterion with self-identification. The concept of race, which hides a prejudice of culture, color, and class (see Bastide 200I), validates the notion of flair and the representation of Māori as staunch dark men. It also suggests that Māori requests for autonomy are regarded as the attempt of one "race" to overpower the other. This contrasts with the expression of a culture that being a minority is not fully represented at the cultural and political level by national rugby institutions and teams and has to constantly justify its own identity and 
face cultural misconstruction and misunderstandings. Given this scenario, the Mãori engagement with mana in the context of rugby will continue to be played out in contradictory ways for some time to come.

\section{Notes}

I The classical rugby nations are the United Kingdom, Ireland, Australia, South Africa, and France.

2 In 2002, I spent three months in Aotearoa/New Zealand. I went back for one year's work experience in 2004-05.

3 When I refer to the everyday realities Māori face, I mean socioeconomic struggles such as poverty, alcoholism, criminality, poor health, and low education; the cultural misunderstandings, prejudice, ignorance, and indifference that Māori experience in non-Māori contexts; and the political tensions between Māori and Pākehā, in which the former strive for further self-determination and the latter accuse them of having become a privileged group-which perpetrates reverse racism. I also include the experiences of Māori in Māori contexts, which encompass creative, dynamic, and vital cultural expressions as well as intragroup conflicts over how to define Māori identity and achieve recognition.

4 See Borell 2005; George 20I 2; Gonzalez 20I0; Mahuika 2006; McCormack 20I 2; McIntosh 2005; Moura-Koçoğlu 20I I.

5 See Turner 1969, I982 regarding the idea of sport as providing a liminal space within society.

6 The words of the Timatanga haka are "Piki ake piki ake, Ki te ara poutama, Ki ngà taumatatanga e, Wairua hinengaro tinana" (Climb up, thrive, to the pathway of knowledge, to achieve excellence spiritually, mentally, physically).

7 The centenary reopened the painful chapter of the Māori exclusion from tours to South Africa during apartheid, recognizing historical experiences of racism in New Zealand rugby. Prominent rugby men like Bill Bush and other Māori leaders called for an apology by the New Zealand Rugby Union for acquiescing to South African requests. The call went unheard until the South African minister of sport apologized and urged both the South African Rugby Union and the NZRU to do the same. The NZRU apologized via media release and claimed that they had already considered the issue and thus consulted the Māori Rugby Board, which instead discouraged them, believing that past Māori administrators would be unfairly condemned and that they should look forward rather than at the past. Many Māori accused the Māori board of not being strong enough to represent them, while questioning one more time the actual inclusiveness and self-determination of Māori Rugby, particularly regarding the Māori team. On the other hand, the event reignited the Pākehā debate over the Māori right to have an all- 
Māori team and its "racist nature" (see Hokowhitu 2009, 2327-2328). However, a Māori young man I talked to blamed both the celebrations and the resulting discussions, arguing they distracted Māori from more urgent issues while dissipating their political energy.

$8 \mathrm{My}$ informants usually self-identified with one or more iwi (tribe).

9 These included three former All Blacks and Māori All Blacks players: Bill Bush, Tane Norton, Dallas Seymour; Matt Te Pou, former Māori All Blacks coach; Whetu Tipiwai, current Māori All Black kaumātua (cultural and spiritual advisor) and member of the Māori Rugby Board; Paul Quinn, Māori member of the NZRU and chairman of the Māori Board; and two former New Zealand female team players: Melodie Robinson and Farah Rangikoepa Palmer, who captained the team and is now an independent member of the Māori Rugby Board.

Io For historical insight on the way rugby became popular among Māori, see Phillips I 996 and Hokowhitu 2004a. For a history of Māori rugby, see Mulholland 2009; the 20I0 Māori Television documentary series Beneath the Māori Moon (based on Mulholland 2009); and Hokowhitu 2005, 2009.

I I See the correspondence between the tribal leader Apirana Ngata and Māori anthropologist Sir Peter Buck in Sorrenson 1986.

I 2 Traditionally performed to welcome visitors to the village in the past and to the marae in modern society, the pōwhiri is a journey whereby Māori negotiate the terms of their engagement and acknowledge each other's tapu (sacredness) and mana. Today it is also performed when New Zealand welcomes official visitors. It consists of the karanga (call), in which a woman from the tangata whenua (hosts) invites the manuhiri (guests) to move on through a melodious chant. On important occasions, the welcoming group performs a haka. In the old days-and today for tourists and prestigious visitors-the ritual would include warriors performing the wero (challenge). These are followed by the whaikorero (formal speeches), which have been described as an oratory battle; the koha (gift exchange); and the hongi, whereby the two groups reconcile and actually engage with each other. A hakari (meal), through which the hosts display their hospitality and the tapu of the guests is lifted, ends the ceremonial.

I3 In her analysis of the whānau in contemporary society, anthropologist Joan Metge noticed the increasing metaphorical use of the word to identify social groups whose formation had nothing to do with descent or affiliation but who modeled themselves on the whānau (I990, 74).

I 4 The erosion of local rugby's popularity began long before professionalization, stemming from societal changes beginning in the I950s: Urbanization and overseas migration partially emptied Māori communities and consequently made for fewer Māori clubs and trophies. Nowadays Māori encounter and play rugby more often at school than within the community. And other sports and kapa haka (Māori performing arts) compete for people's time, both as participants and audiences. 
I 5 See the cases of Pacific Islander rugby union and league players and American Samoan gridiron footballers (Clément, Kwauk, and Uperesa, this issue) as well as the case of the Indian footballers in Mills and Dimeo 2002.

I 6 Not all Adidas campaigns draw on Māori imagery as heavily as the one I referred to in the opening paragraph of this article. As I noted, that advertisement is also to be contextualized in a specific historical moment-the advent of rugby professionalism with its money and worldwide visibility. However, there is always a Māori element in the advertisements. The presence of the haka is a constant, and in some ads we also find the theme of the ancestors, depicted according to the Māori carving style. Ideas like "one country, one team, one jersey" also indirectly use Māori as part of Adidas branding.

I7 Generally speaking, racism toward Māori in sport seems to be a taboo subject in New Zealand society (see Hippolite and Bruce 2010).

\section{References}

Appadurai, Arjun

1996 Modernity at Large: Cultural Dimensions of Globalization. Minneapolis: University of Minnesota Press.

Archetti, Eduardo P

I999 Masculinities: Football, Polo and the Tango in Argentina. Oxford, UK: Berg.

Bale, John, and Mike Cronin, editors

2002 Sport and Postcolonialism. Oxford, uk: Berg.

Bastide, Roger

200I Le Prochain et le lointain. Paris: Éditions L'Harmattan. Originally published in 1970 .

Besnier, Niko, and Susan Brownell

2012 Sport, Modernity, and the Body. The Annual Review of Anthropol-

Borell, Belinda ogy 4I:443-459.

2005 Living in the City Ain't So Bad: Cultural Diversity of South Auck-

Bourdieu, Pierre land Rangatahi. Master's thesis, Massey University, New Zealand.

I978 Sport and Social Class. Social Science Information I7:8 I9-840.

I990 In Other Words: Essays toward a Reflexive Sociology. Stanford, CA: Stanford University Press.

Calabrò, Domenica Gisella

20I I The Indigenization of Rugby in New Zealand and Its Role in the Process of Māori Identity Definition. PhD dissertation, University of Messina, Italy. 
Coates, Ken S, and Paul G McHugh, editors

I998 Living Relationships/Kōkiri Ngātahi: The Treaty of Waitangi in the New Millennium. Wellington: Victoria University Press.

Dewey, Robert

2009 Embracing Rugby and Negotiating Inequalities in the Pacific Islands.

In Proceedings of the 2008 International Indigenous Traditional

Knowledge Conference, Te Tatau Pounamu-The Greenstone Door.

Auckland: Nga Pae o te Maramatanga/National Institute of Research

Excellence for Māori Development and Advancement, University of Auckland.

Durie, Mason

I998 Te Mana, Te Kāwanatanga: The Politics of Māori Self-Determination. Auckland: Oxford University Press.

George, Lily

2OI 2 Expressions of Māori Multiplicity in (Re)Connection to Ngā Taonga

Tuku Iho. Social Identities: Journal for the Study of Race, Nation

Gonzalez, Christina M and Culture I 8 (4): 435-450.

2010 "Be(com)ing" Ngāti Kahungunu in the Diaspora: Iwi Identity and Social Organisation in Wellington. MA thesis, Victoria University of

Grainger, Andrew Wellington.

2009 Rugby Island Style: Paradise, Pacific People, and the Racialisation of Athletic Performance. Junctures: The Journal for Thematic Dialogue I 2:45-63.

Guttmann, Allen

I990 Rituals, Records, Responses. In Ritual and Record: Sport Records and Quantification in Pre-Modern Societies, edited by John Marshall Carter and Arnd Krüger, I 53-160. Westport, Ст: Greenwood.

Harris, John

2010 Rugby Union and Globalization: An Odd-Shaped World. Basingstoke, uk: Palgrave Macmillan.

Hippolite, Holly Raima, and Toni Bruce

20I0 Speaking the Unspoken: Racism, Sport and Māori. Cosmopolitan

Civil Societies: An Interdisciplinary Journal 2 (2): 23-45.

Hokowhitu, Brendan

2003 Race Tactics: The Racialised Athletic Body. Junctures I:2 I-34.

2004a "Physical Beings": Stereotypes, Sport and the "Physical Education" of New Zealand Māori. In Ethnicity, Sport, Identity: Struggles for Status, edited by J A Mangan and Andrew Ritchie, I92-2 I8. London: Frank Cass. 
2004b Tackling Māori Masculinity: A Colonial Genealogy of Savagery and Sport. The Contemporary Pacific I 5:259-284.

2005 Rugby and Tino Rangatiratanga: Early Māori Rugby and the Formation of Māori Masculinity. Sporting Traditions: Journal of the Australian Society for Sports History 2I (2): 75-95.

2008 Authenticating Māori Physicality: Translations of "Games" and "Pastimes" by Early Travellers and Missionaries to New Zealand. International Journal of the History of Sport 25 (Io): I355-I 373.

2009 Māori Rugby and Subversion: Creativity, Oppression, Domestication and Decolonization. International Journal of the History of Sport 26 (I6): 23 I 4-2334.

Jackson, Steven, and Brendan Hokowhitu

2005 Sport, Tribes and Technology: The New Zealand All Blacks Haka and the Politics of Identity. In Sport and Corporate Nationalisms, edited by Michael L Silk, David L Andrews, and C L Cole, 67-82. Oxford, uk: Berg.

King, Michael

I983 Maori: A Photographic and Social History. Auckland: Reed.

Lévi-Strauss, Claude

I962 La pensée sauvage. Paris: Plon.

Mahuika, Nēpia

2006 Being Māori Tūturu: Māori Life Narratives and Contemporary Identities. MA thesis, University of Waikato.

McCormack, Fiona

20I2 Indigeneity as Process: Māori Claims and Neoliberalism. Social Identities: Journal for the Study of Race, Nation and Culture I 8 (4):

McIntosh, Tracey 4I 7-434.

2005 Maori Identities: Fixed, Fluid, Forced. In New Zealand Identities: Departures and Destinations, edited by James H Liu, Tim McCreanor, Tracey McIntosh, and Teresia Teaiwa, 38-5 I. Wellington: Victoria University Press.

Metge, Joan

I976 The Maoris of New Zealand. Revised edition. London: Routledge \& Kegan Paul.

I986 In and Out of Touch: Whakamaa in Cross Cultural Context. Wellington: Victoria University Press.

I990 Te Rito o Te Harakeke: Conceptions of the Whaanau. Journal of the Polynesian Society 99 (I): 55-9I.

I995 New Growth from Old: The Whannau in the Modern World. Wellington: Victoria University Press. 
Metge, Joan, and Patricia Kinloch

I984 Talking Past Each Other: Problems of Cross Cultural Communication. Revised edition. Wellington: Victoria University Press.

Mills, James, and Paul Dimeo

2002 "When Gold Is Fired It Shines": Sport, the Imagination and the Body in Colonial and Postcolonial India. In Sport and Postcolonialism, edited by John Bale and Mike Cronin, I07-I22. Oxford, uk: Berg.

Moura-Koçoğlu, Michaela

20I I Narrating Indigenous Modernities: Transcultural Dimensions in Contemporary Māori Literature. Amsterdam: Rodopi.

Mulholland, Malcolm

2009 Beneath the Māori Moon: An Illustrated History of Māori Rugby. Wellington: Huia Publishers.

Palmer, Farah Rangikoepa

2005 Māori Sport and Its Management. In Sport Business Management in Aotearoa/New Zealand, edited by Sarah Leberman, Chris Collins, and Linda Trenberth, 62-88. Nelson, NZ: Thomson.

Phillips, Jock

I996 The Hard Man: Rugby and the Formation of Male Identity in New Zealand. In Making Men: Rugby and Masculine Identity, edited by John Nauright and Timothy J L Chandler, 7I-90. London: Frank Cass.

Ryan, Greg

I993 Forerunners of the All Blacks. Christchurch: Canterbury University Press.

Ryan, Greg, editor

2005 Tackling Rugby Myths: Rugby and New Zealand Society, I8542004. Dunedin: Otago University Press.

2008 The Changing Face of Rugby: The Union Game and Professionalism since I995. Cambridge: Cambridge Scholars Publishing.

Sahlins, Marshall

I999 What Is Anthropological Enlightenment? Some Lessons of the Twentieth Century. Annual Review of Anthropology 28:i-xxiii.

Scherer, Jay, and Steven Jackson

2007 Sports Advertising, Cultural Production and Corporate Nationalism at the Global-Local Nexus: Branding the New Zealand All Blacks. Sport in Society Io (2): 268-284.

Sin, Isabelle, and Steven Stillman

2005 The Geographical Mobility of Māori in New Zealand. Motu Working Paper 05-05. Wellington: Motu Economic and Public Policy Research. 
Sorrenson, M P K, editor

I986 Na to Hoa Aroha, from Your Dear Friend: The Correspondence between Sir Apirana Ngata and Sir Peter Buck, I925-50. 3 volumes. Auckland: University Printing Services.

Teaiwa, Teresia, and Sean Mallon

2005 Ambivalent Kinships? Pacific People in New Zealand. In New Zealand Identities: Departures and Destinations, edited by James H Liu, Tim McCreanor, Tracey McIntosh, and Teresia Teaiwa, 207-229. Wellington: Victoria University Press.

Te Rito, Patrick R

2007 Māori Leadership: What Role Can Rugby Play? MA Thesis, Auckland University of Technology.

Turner, Victor

I966 The Ritual Process: Structure and Anti-Structure. Ithaca, NY: Cornell University Press.

I982 From Ritual to Theatre: The Human Seriousness of Play. New York: Performing Arts Journal Publications.

Walker, Ranginui

2004 Ka Whawhai Tonu Matou: Struggle Without End. Auckland: Penguin Books.

Winiata, Maharaia

I967 The Changing Role of the Leader in Maori Society. Auckland: Blackwood and Janet Paul.

\section{Abstract}

Since the advent of professional rugby, Māori have gained international visibility and attractiveness. The representation of the New Zealand rugby team revolves around their integration and the incorporation of their warrior tradition, suggesting a strong connection between rugby and contemporary Māori society. Rugby has indeed been the object of a process of indigenization, fulfilling goals of sociocultural continuity, political acknowledgment, and, in the professional era, upward social mobility. Nevertheless, rugby has also partly fulfilled its role as a tool of colonization in creating and sanctioning power differentials. Drawing on my ethnographic fieldwork in New Zealand, this article examines the relationship between Māori and rugby as a dialectic phenomenon that has resulted in the diversification of Māori experiences and perceptions of rugby and attests to the heterogeneity of Māori life experiences, aspirations, and formulations of indigeneity in contemporary society.

KEYWORDS: Māori, New Zealand, rugby, indigenization, flair, branding, body 